\title{
Ada Apa dengan Dewan Pengawas Syariah di Koperasi Simpan Pinjam dan Pembiayaan Syariah?
}

\author{
Choirul Absor ${ }^{1}$, Kharis Fadlullah Hana ${ }^{2}$, Fatikha Rizqya Nur ${ }^{3}$ \\ 1,2,3Institut Agama Islam Negeri Kudus, Kudus \\ $\triangle 1$ irulsejati27@gmail.com, $₫$ 2kharis@iainkudus.ac.id, $₫$ 3fatikharizqya14@gmail.com
}

\begin{abstract}
: This study aims to determine the role of the Sharia Supervisory Board in supervising Sharia Savings and Loan Cooperatives (KSPPS) so that operations do not come out of sharia provisions. Sharia Supervisory Board includes legal assistants who have the duty to ensure and conduct supervision so that Sharia Financial Institutions are in sharia provisions. Savings and Loan Cooperatives and Sharia Financing are financial institutions that are socially based and in their activities are based on moral principles by considering haram and lawfulness of a business that is run in accordance with Islamic regulations. The method used to conduct this research is qualitative. The data source uses secondary data and primary data by collecting data in the form of interviews and documents. Based on the results of observations on KSPPS Berkah Abadi Gemilang that Supervision conducted by DPS there is still an obstacle that causes less optimal supervision, namely members of sharia supervisors who do not understand muamalah fiqh, mastery of economics and DPS rarely make office visits. In addition, one member of the DPS also does not yet have a certificate of proof of passing the exam from $D S N-M U I$ or other standard certificates, in this case at least the results of the certificate provide a guarantee that the Sharia Supervisory Board has passed the feasibility test to become the Sharia Supervisory Board. KSPPS Berkah Abadi Gemilang in practice also still has errors, the Ba'l Bi'saman Ajil contract which is supposed to be a sale and purchase agreement but made as a financing and error in determining the margin based on the presentation of the money lent.
\end{abstract}

Keywords $\quad$ : Sharia Compliance, Sharia Supervisory Board, KSPPS

\section{LATAR BELAKANG}

Terdapat dua macam lembaga keuangan di negara indonesia, yaitu lembaga keuangan berbentuk bank dan lembaga keuangan non bank. Kedua lembaga keuangan ini dalam beroperasi ada yang menggunakan ketentuan syariah dan ada juga yang tidak menggunakan ketentuan syariah (konvensional). salah satu unsur mendasar yang menentukan perbedaan lembaga keuangan syariah dengan konvensional ialah terletak dalam kepatuhan pada prinsip-prinsip syariah.

Keepatuhan dalam kegiatan lembaga keuangan syariah dengan mengikuti ketentuan-ketentuan syariah adalah suatu keharusan. Pihak yang mempunyai wewenang dalam memberikan pengawasan mengenai penerapan kepatuhan syariah pada lembaga keuangan syariah adalah dewan pengawas syariah (DPS) yang merupakan suatu lembaga internal dan independen. Dewan pengawas syariah 
betugas untuk memastikan dan mengawasi bahwa lembaga keuangan syariah dalam menjalankan kegiatanya sesuai dengan ketentuan syariah.

Tugas-tugas dari Dewan Pengawas Syariah antara lain ialah memberikan pengawasan secara rutin terhadap lembaga keuangan syariah yang berada bawah pengawasannya. Dewan Pengawas Syariah meberikan laporan mengenai perkembangan produk dan operasional lembaga keuangan syariah yang di awasinya kepada Dewan Syariah Nasional paling sedikit 2 kali dalam 1 tahun anggaran. Dewan Pengawas Syariah merumuskan permasalahan-permasalahan yang memembutuhkan bantuan dan penjelasan kepada Dewan Syariah Nasional.

Keberadaan dewan pengawas syariah pada lembaga keuangan syariah sangat penting dalam mewujudkan kepatuhan syariah. Hal demikian berhubungan erat dengan peran lembaga keuangan syariah dalam mensyariahkan perekonomian masyarakat. Selain itu pada pengawasan syariah adalah untuk memberikan perlindungan kepada konsumen dalam pemanfaatan jasa keuangan syariah. Untuk itu pengawasan terhadap prinsip syariah tidak cuma sekedar di maknai pada pengawasan akad-akad dalam transaksi keuangan syariah saja, akan tetapi dapat memberikan opini kepada pengelola dan manajemen untuk memberikan perlindungan kepada konsumen dari segi pemanfaatan kehalalan pada transaksi keuangan syariah.

Penelitian yang di lakukan Luqman Nurhisam (2016) menyatakan bahwa dewan pengawas syariah (DPS) yang memiliki wewenang untuk melakukan pengawasan dalam kepatuhan syariah, mempunyai tugas yang di atur pada peraturan hukum yang tegas. Jika di lihat dari peraturan perundang-undangan serta pengaplikasian yang di lakukan oleh lembaga keuangan syariah, Dewan Pengwas Syariah di posisikan pada tempat yang paling strategis. Keberadaan DPS sangat menentukan terwujudnya kepatuhan syariah yang menjadikan suatu unsur utama untuk keberlangsungan suatu usaha pada lembaga keuangan syariah.

Dewan pengawas syariah dalam menjalankan tugasnya harus mempunyai keilmuan khusus, yaitu ilmu fiqh muamalah dan ilmu perekonomian islam modern. Kesalahan yang telah di lakukan lembaga kuangan syariah saat ini ialah menjadikan dewan pengawas syariah (DPS) karena kharisma dan ketenarannya di kalangan masyarakat, tidak karena mempunyai keilmuan di bidang ekonomi dan perbankkan syariah. Anggota dewan pengawas syariah masih banyak yang belum tahu mengenai ilmu perbankkan dan lembaga keuangan syariah (LKS), apalagi mengenai ilmu-ilmu ekonomi keuangan islam seperti akutansi, sehingga menjadikan ketidak maksimalan dalam melakukan pengawasan. Dewan pengawas syariah (DPS) seharusnya memahami ilmu yang berkaitan dengan keuangan syariah seperti ilmu ekonomi moneter. Dengan demikian maka tidak akan ada lagi dewan pengawas syariah yang menjadikan margin jual beli murabahah dengan bunga. Namun pada kenyataannya, masih banyak dewan pengawas syariah yang belum dapat membedakan margin murabahah dengan bunga, karna keterbatasan ilmu yang dimilikinya.

Pada penelitian yang di lakukan Neneng Nurhasanah (2013) menyatakan bahwa SDM Dewan Pengawas Syariah perlu ditingkatkan kuantitas maupun kualitasnya agar 
kesalahan-kesalahan yang tidak sesuai dengan hukum islam dapat lebih di minimalisir. Diantaranya adalah mengenai penguasaan keilmuan yang meliputi ilmuilmu ekonomi dan keuangan maupun ilmu fiqh muamalah dan ushul fiqhnya. Keberadaan DPS yang di harapkan tidak hanya dalam struktural saja, akan tetapi harus ada bukti nyata dari hasil kinerjanya.

Pada tahun 1999 MUI menerbitkan Surat ketetapan No.754/MUI/II/1999 mengenai Dewan Syariah Nasional (DSN) yang mempunyai tugas mengontrol Dewan Pengawas Syariah (DPS) dalam Lembaga Keuangan Syariah (LKS) diseluruh Indonesia. Tugas utama DSN ialah merumuskan, menggali dan mengkaji terhadap nilai dan ketentuan hukum Islam (syariah) untuk di gunakan sebagai panduan pada operasional LKS agar ada kesamaan fatwa, serta memberikan pengawasan dalam penerapannya. Dengan dikeluarkannya Fatwa MUI mengenai Dewan Syariah Nasional tersebut menjadikan tambah kuatnya struktur kelembagaan keuangan syariah, sehingga dapat memotivasi pertumbuhan lembaga keuangan syariah dan dapat mempengaruh munculnya lembaga-lembaga keuangan yang menggunakan prinsip syariah, salah satunya adalah lembaga Koperasi Syariah yang banyak dikenal dengan sebutan Baitul Maal Wa Tamwil (BMT).

Koperasi syariah ialah suatu lembaga perekonomi mikro yang sudah memberikan bantuan lumayan besar untuk mengembalikan perekonomi di Indonesia yang sempat rubuh. Koperasi Syariah tetap bertahan kokoh di tengah-tengah krisisnya ekonomi dan moneter yang melanda perekonomi di Indonesia. Oleh sebab itu, koperasi syariah seharusnya mampu mengamati secara teliti dan seksama disetiap pertumbuhan ekonomi, baik dalam sekala kecil (mikro) maupun besar (makro). Dalam petumbuhan usaha mikro dan makro, maka lembaga keuangan seperti koperasi syariah sangat berperan penting dalam perkembangannya.

Perkembangan Koperasi Simpan Pinjam dan Pembiayaan Syariah (KSPPS) dianggap dari berbagai pihak masih terjadi keterlambatan, ini terjadi pada tahun 2018. Hal itu dibuktikan dalam laporan data bulanan tahun 2017 yang direkap oleh Induk Koperasi Syariah (Inkopsyah), penghasilan keseluruhan dari semua anggota Inkopsyah yang totalnya mencapai 498 koperasi syariah yang berasal dari 27 provinsi terjadi penyusutan. Tertulis penghasilan keseluruhan dari semua anggota koperasi Inkopsyah pada tahun 2017 mencapai 25,175 miliar rupiah, dari laporan 31,166 miliar rupiah dalam tahun 2016 sekitar 19,22 persen. Pada tahun 2016 juga mengalami penurunan di bandingkan dari tahun 2015 yang sampai 40,478 milyar rupiah, anjlok sekitar 21,8 persen.

Koperasi syariah yang berdiri di Indonesia salah satunya adalah KSPPS Berkah Abadi Gemilang. KSPPS Berkah Abadi Gemilang merupakan satu diantara koperasi di Jepara yang beralamat di Jl. Mbaleg - Cemoro Kembar, Troso Pecangaan Jepara (Perempatan Troso Tengah). Berdirinya KSPPS Berkah Abadi Gemilang berawal dari keinginan seorang mahasiswa UNISNU Jepara yang bercita-cita untuk membuat sebuah usaha yang bisa bermanfaat bagi banyak orang yang bernama Agus Setiawan. KSPPS Berkah Abadi Gemilang diresmikan pada 1 Januari 2012 dan hingga sekarang telah mempunyai enam cabang yang tersebar di wilayah Jepara. 
Seperti koperasi syariah lainnya KSPPS Berkah Abadi Gemilang dalam pengelolaan (manajemen) maupun operasionalnya berdasarkan pada prinsip syariah. Dalam peraturan menteri koperasi dan UKM mengeluarkan surat No.11/PER/M.KUKM/XII/2017 mengenai Pelaksanaan Kegiatan Usaha Simpan Pinjam Dan Pembiayaan Syariah Oleh Koperasi. Menetapkan bahwa koperasi yang melakukan kegiatan usaha simpan pinjam dan pembiayaan syariah harus memiiliki Dewan Pengawas Syariah yang di tetapkan dalam rapat anggota tahunan (RAT). Dewan Pengawas Syariah minimal berjumlah dua orang dan sebagian harus mempunyai sertifikat dari DSN-MUI atau sertifikat standar kompetensi lainnya yang di keluarkan oleh lembaga yang sudah mendapatkan lisensi sesuai dengan ketentuan peraturan perundang-undangan. Dewan pengawas syariah betugas memberi saran dan nasehat kepada pengurus dan memberikan pengawasan terhadap kegiatan koperasi agar sesuai dengan ketentuan syariah.

Berdasarkan hasil observasi yang di lakukan peneliti bahwa KSPPS Berkah Abadi Gemilang Jepara sudah memiliki tiga DPS. Penulis juga mendapat informasi mengenai dewan pengawas syariah (DPS) di KSPPS Berkah Abadi Gemilang, bahawa DPS jarang ke kantor untuk melakukan pengawasan, karena selain bekerja sebagai DPS pada koperasi syariah tersebut DPS juga memiliki pekerjaan lain, sehingga menjadi DPS bukanlah satu-satunya pekerjaan yang mereka tekuni saat ini. Hal ini akan mempengaruhi aktifnya DPS berada di kantor untuk melakukan pengawasan.

Sebagai DPS yang di tunjuk oleh Dewan Syariah Nasional (DSN) seharusnya bertanggung jawab secara penuh terhadap pengawasan pada koperasi syariah tersebut. Tidak menutup kemungkinan bahwa penyelewengan atau kesalahan dalam transaksi akan terjadi setiap hari, sedangkan DPS jarang sekali ke kantor untuk melakuakan pengawasan. Maka peran DPS pada KSPPS Berkah Abadi Gemilang belum terlaksana dengan baik khususnya dalam sistem penerapan jadwal kunjungan rutin DPS sehingga masih harus dikoreksi kembali.

\section{TEORI DAN METODE}

\subsection{Dewan Pengawas Syariah}

Kata "dewan" dari kamus besar bahasa Indonesia (KBBI) ialah majlis atau suatu badan yang didalamnya terdapat beberapa orang yang bertugas memutuskan sesuatu dengan melalui diskusi atau musyawarah. Pengawas berasal dari kata "awas" yang mempunyai arti dapat melihat dengan baik, tajam dalam penglihatan. Sedangkan syariah ialah suatu tatanan atau aturan islam yang menetapkan peraturan hidup seorang muslim baik hubungan antara manusia dengan Allah, hubungan manusia dengan sesama manusia dan hubungan manusia dengan alam sekitar sesuai dengan yang diajarkan dalam Al-Quran dan Hadis. (Departemen Pendidikan Nasional, 2012:322,13 Neneng Nurhasanah, 2013:13).

Dewan Pengawas Syariah ialah suatu badan yang mempunyai tugas untuk mengawasi jalannya operasional lembaga keuangan syariah supaya sesuai dengan ketentuan syariah yang sudah di fatwakan oleh DSN. Keberadaan Dewan Pengawas Syariah ini berada di bawah Rapat Umum Pemegang saham atau 
sepadan dengan pengurus dalam struktur suatu lembaga keuangan syariah, salah satunya pada koperasi simpan pinjam dan pembiayaan syariah. Hal ini bertujuan untuk menjamin efektifitas Dewan Pengawas Syariah dalam menjalankan tugasnya sebagai pengawas. (Andri Soemitra, 2009:43; Herry Sutanto dan Khaerul Umam, 2013:413).

Berdasarkan keterangan yang ada di atas, maka dapat di simpulkan bahwa Dewan Pengawas Syariah (DPS) ialah suatu badan yang mempunyai tugas untuk melakukan pengawasan terhadap segala aktivitas di dalam lembaga keuangan syariah agar sesuai dengan ketentuan syariah. Dewan Pengawas Syariah juga mempunyai tugas lain yaitu meneliti dan membuat usulan-usulan produk baru dari lembaga keuangan yang di awasinya. Dengan demikian, Dewan Pengawas Syariah adalah orang paling awal yang melakukan penyaringan terhadap produk sebelum produk tersebut di aplikasikan dan di fatwakan pada Dewan Syariah Nasional. (Muhammad syafi'i Antonio, 2001: 31)

\subsection{Dasar Hukum Dewan Pengawas Syariah}

Telah di jelaskan bahwa diantara bagian terpenting KSPPS ialah harus mempunyai Dewan Pengawas Syariah. Mengenai aturan dibentuknya Dewan Pengawas Syariah dan penetapannya tertuang dalam (Q.S. At-Taubah 9 : 105)

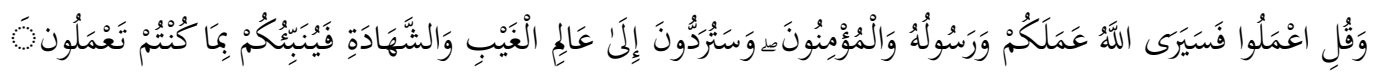

Artinya: "dan katakanlah: bekerjalah kamu, maka Allah dan Rasulnya serta orang mu'min akan melihat pekerjaan itu dan kamu akan di kembalikan kepada (Allah) yang mengetahui akan yang Ghaib dan yang nyata lalu diberikannya kepada kamu apa yang telah kamu kerjakan. (Alquran 2006: 203).

Kewajiban untuk membentuk DPS ini secara tegas di nyatakan pada ketentuan pasal 32 UU Nomor 21 Tahun 2008 yang menyatakan bahwa DPS wajib di bentuk di lembaga keuangan syariah dan lembaga mikro syariah seperti KSPPS. Dewan Pengawas Syariah sebagaimana yang dimaksud dalam pengangkatannya dilakukan oleh rapat umum pemegang saham atas anjuran dari Majelis Ulama Indonesia. Dewan Pengawas Syariah sebagaimana dimaksud di atas mempunyai tugas untuk memberikan saran dan nasihat kepada pengurus serta mengawasi jalannya kegiatan operasional Lembaga Keuangan Syariah agar sesuai dengan ketentuan syariah. (Rachmadi Usman, 2009: 79-80).

\subsection{Peran Dewan Pengawas Syariah}

Dewan Pengawas Syariah mempunyai peran yang sangat penting dalam lembaga keuangan syariah, agar lembaga keuangan syariah dalam memberikan pelayanan kepada nasabah atau anggotanya tidak bertentangan dengan ketentuan syariah. Karena pelayanan yang diberikan tidak sekedar hanya bertujuan untuk memperoleh laba seperti yang di lakukan oleh lembaga keuangan konvensional, namun lembaga keuangan syariah dalam operasionalnya menerapkan prinsip syariah yang sesuai dengan Al-Qur'an dan As-Sunnah. Adapun peran Dewan Pengawas Syariah didalam lembaga keuangan syariah adalah sebagai berikut: 
1) Dewan Pengawas Syariah memberikan pengawasan pada lembaga keuangan syariah yang berada dibawah pengawasannya secara periodik.

2) Dewan Pengawas Syariah berhak memberikan satan dan masukan mengenai pengembangan lembaga keuangan syariah kepada pengurus lembaga yang bersangkutan dan kepada DSN.

3) Dewan Pengawas Syariah berkewajiban membeikan laporan mengenai operasional lembaga keuangan syariah yang di awasinya kepada DSN paling sedikit 2 kali dalam 1 tahun anggaran.

4) Dewan Pengawas Syariah merumuskan permasalahan-permasalahan yang membutuhkan saran dari DSN. (Bagya Agung Prabowo dan Jasri Bin Jamal, 2017: 121; Burhanuddin, 2013: 167).

Peran Dewan Pengawas Syariah berdasarkan pada Peraturan Menteri Koperasi dan Usaha Kecil Menengah No: 11/PER/M.KUKM/XII/2017 mengenai Pelaksanaan Kegiatan Usaha Simpan Pinjam dan Pembiayaan Syariah dalam Koperasi adalah:

1) Memberikan saran dan nasehat untuk pengawas dan pengurus serta memberikan pengawasan pada operasional KSPPS supaya sesuai dengan ketentuan syariah.

2) Memastikan dan memberikan penilaian pemenuhan kepatuhan syariah dalam pedoman kegiatan dan produk yang telah di keluarkan oleh KSPPS.

3) Memberikan pengawasan terhadapa perkembangan produk baru.

4) Meminta fatwa dari DSN - MUI terhadap produk yang belum ada fatwanya.

5) Memberikan evaluasi secara berkala pada produk simpanan maupun pembiayaan syariah.

6) Memberikan laporan atas pelaksanaan tugas pengawasannya kepada DSN MUI minimal 1 (satu) tahun sekali. (Peraturan Menteri Koperasi dan UKM 2017).

Mekanisme kerja Dewan Pengawas Syariah (DPS) dapat di ilustrasikan pada gambar berikut: (Heri Sudarsono, 2004: 43).

\section{Gambar 2.1}

Mekanisme Kerja Dewan Pengawas Syariah

Rapat DPS dgn Pimpinan

Dan Bag/Dep Terkait

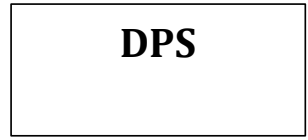

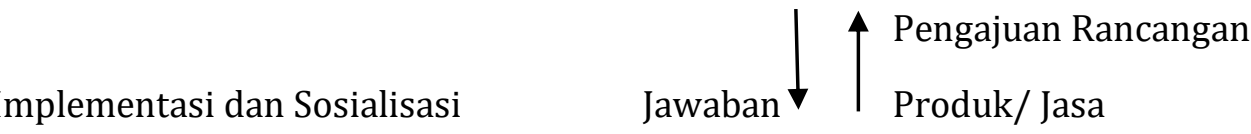

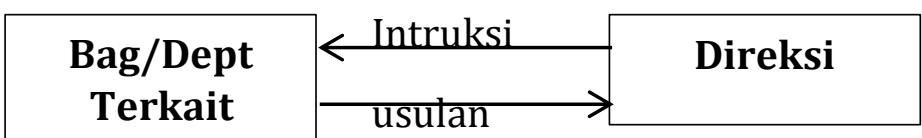

\subsection{Kepatuhan Syariah (Sharia Compliance)}

Pengertian kepatuhan (Compliance) dalam Peraturan Bank Indonesia (PBI) No. 13/2/PBI/2011 mengenai Pelaksanaan fungsi Kepatuhan ialah tindakan, penilaian, dan perbuatan yang memberikan dukungan untuk terwujudnya kepatuhan pada peraturan lembaga keuangan dan peraturan undang-undang yang berlaku, termasuk dalam kepatuhan syariah bagi lembaga keuangan syariah. (Edi Susilo, 2017: 125). 
Kepatuhan Syariah (Sharia Compliance) adalah sesuatu hal yang sangat penting bagi industry keuangan syariah baik untuk perbankkan ataupun lembaga keuangan bukan bank. Pimpinan lembaga keuangan syariah harus paham mengenai fiqh muamalah dalam melakukan kegiatan operasional di dalam lembaganya. Indikator kepatuhan syariah pada lembaga keuangan syariah adalah kegiatan operasional dan produk-produknya harus sesuai dengan fatwa-fatwa DSN - MUI. Hal itu di dukung dengan mengharuskan keberadaan DPS untuk semua lembaga keuangan yang beroperasional berdasarkan prinsip syariah. DPS mempunyai tugas mengawasi bagaimana penerapan akad yang di jalankan oleh koperasi syariah tersebut, apakah sesuai dengan ketentuan syariah atau tidak. (Luqman Nurhisam, 2016: 24).

Kepatuhan syariah merupakan unsur penting yang menjadi pedoman penilaian terhadap kesehatan koperasi simpan pinjam dan pembiayaan Syariah (KSPPS) dan unit jasa keuangan syariah (UKJS). Kegunaan dari kepatuhan adalah suatu perilaku atau langkah untuk membuktikan bahwa kegiatan usaha yang di lakukan oleh koperasi sudah sesuai dengan ketentuan syariah sebagaimana yang sudah di anjurkan. Oleh karena itu di samping eksistensi dewan pengawas syariah (DPS), kesadaran dari masing-masing praktisi terhadap prinsip-prinsip kesyariahan juga akan menjadi sangat menentukan terwujudnya kepatuhan syariah tersebut. (Burhanuddin S, 2013: 339).

Ketidak patuhan terhadap prinsip syariah akan menimbulkan dampak negative pada kondisi lembaga keuangan syariah itu sendiri, karena berpotensi pada kegagalan yang dapat mengakibatkan terhalangnya suatu sistem keuangan di negara. Selain itu kepatuhan syariah juga merupakan bagian unsur dari suatu penilain terhadap tingkat kesehatan dalam lembaga keuagan syariah. Pemeliharaan kesehatan pada lembaga keuangan syariah juga termasuk pemeliharaan terhadap kepercayaan masyarakat, sehingga apabila lembaga keuangan syariah tersebut lalai dalam menjaga tingkat kesehatannya, temasuk lalai dalam penerapan prinsip syariah, maka masyarakat juga akan hilang rasa percayanya pada lembaga keuangan syariah tersebut. (Aan Zainul Anwar dan Mohammad Yunies Edward, 2016: 259-260).

Dari pengertian di atas, bisa di simpulkan bahwa Kepatuhan Syariah (Sharia Compliance) adalah suatu bentuk kepatuhan terhadap lembaga keuangan syariah untuk memenuhi penerapan prinsip syariah dalam kegiatan operasionalnya. Lembaga keuangan syariah harus beroperasi sesuai kaidah-kaidah islam khususnya menyangkut cara bermuamalah. prinsip-prinsip tersebut wajib ada pada akad-akad dalam lembaga keuangan syariah, salah satunya pada KSPPS.

Kaidah transaksi dalam bermuamalah adalah di perbolehkan kecuali terdapat dalil yang melarang (Al-ahlu fil muamalah al ibahah). Kaidah ini menjelaskan bahwa ruang lingkup dari transaksi muamalah sangat luas, bahkan keinginan berinovasi bisa di terima. Berbeda dengan ibadah yang ruang lingkupnya sangat terbatas, tidak bisa untuk berinovasi. Larangan tranksi dalam muamalah dapat di sederhanakan dalam tiga macam yaitu tidak ada riba, gharar, dan maysir. (Sepky Mardian, 2015: 58). 


\subsection{Metode Penelitian}

Jenis penelitian ini adalah penelitian deskriptif kualitatif. (Afrizal, 2015: 13). Penelitian ini di maksudkan untuk menganalisis mengenai peran dewan pengawas syariah (DPS) dalam kepatuhan syariah pada KSPPS Berkah Abadi Gemilang Jepara. Penelitian ini di pusatkan pada permasalahan tertentu dan pada ruang lingkup tertentu sehingga bisa di golongkan dalam jenis pendekatan studi fenomenologis. Sebagaimana di ungkapkan bahwa studi fenomenologis adalah jenis pendekatan dalam penelitian kualitatif yang di gali adalah usaha untuk menemukan realitas yang tampak dengan melibatkan pengujian yang teliti dan seksama dalam kesadaran pengalaman manusia.

Adapun lokasi peneliti ini bertempat di Jl. Mbaleg - Cemoro Kembar, Troso Pecangaan Jepara (Perempatan Troso Tengah). Pada subyek penelitian ini adalah Ketua Dewan Pengawas Syariah (DPS), Manager, karyawan dan anggota KSPPS Berkah Abadi Gemilang. (Muh. Fitrah dan Luthfiyah, 2017: 152). Data primer dalam penelitian ini ialah Ketua Dewan Pengawas Syariah (DPS), Manager, Kayawan dan anggota yang ada di KSPPS Berkah Abadi Gemilang Jepara. (Sumardi Suryabrata, 2005). Data sekunder yang akan di peroleh pada penelitian ini dari sumber yang sudah ada untuk kemudian di olah lebih lanjut, seperti buku-buku yang berkaitan dengan Dewan Pengawas Syariah. (Andi Prastowo, 2016: 27-28).

\section{HASIL DAN PEMBAHASAN}

\subsection{Peran Dewan Pengawas Syariah di KSPPS Berkah Abadi Gemilang Jepara \\ 3.1.1 Sejarah dan Kedudukan DPS KSPPS Berkah Abadi Gemilang}

Kewajiban untuk membentuk DPS ini telah di nyatakan dengan tegas dalam ketentuan pasal 32 Undang-Undang Nomor 21 Tahun 2008 yang menetapkan bahwa DPS wajib di bentuk di lembaga keuangan syariah dan lembaga mikro syariah seperti KSPPS. Dewan Pengawas Syariah dalam penetapannya di angkat oleh rapat umum pemegang saham atas rekomendasi dari Majelis Ulama Indonesia. KSPPS Berkah Abadi Gemilang ialah salah satu lembaga keuangan syariah yang sudah membentuk dan menetapkan DPS pada kedudukan yang penting untuk menjadi pengawas yang mempunyai peran dalam menjaga dan mengawasi supaya KSPPS Berkah Abadi Gemilang senantiasa berada pada jalur yang sesuai dengan prinsip-prinsip syariah, Penempatan kedudukan DPS yang penting ini dapat dilihat dalam struktur organisasi yang di tempatkan pada posisi paling tinggi sejajar dengan pengurus dan pengawas.

Keberadaan DPS sudah ada sejak awal berdirinya KSPPS Berkah Abadi Gemilang. Prosedur penetapanya Dewan Pengawas Syariah di KSPPS Berkah Abadi Gemilang adalah melalui RAT (Rapat Anggota Tahunan), namun tidak menggunakan prosedur DSN-MUI (Dewan Syariah Nasional-Majelis Ulama Indonesia) dari pusat ataupun daerah dalam pengangkatan atau penetapannya. Bahkan tidak melalui rekomendari dari DSN-MUI. Tujuan ditetapkannya DPS di 
KSPPS Berkah Abadi Gemilang adalah untuk mengawasi dan memastikan operasionalnya agar senantiasa berjalan berdasarkan ketentuan syariah.

ketentuan syariah adalah segala sesuatu yang berlandaskan dengan sumber hukum dari al-Qur'an dan Sunnah. Artinya, pada kegiatan penyimpanan dana maupun pembiayaan serta dalam melayani jasa koperasi syariah harus berdasarkan dengan aturan perjanjian (akad) sesuai dengan aturan dalam islam sebagaimana di fatwakan oleh lembaga yang mempunyai wewenang dalam penetapan fatwa di bidang syariah, yaitu DSN-MUI. Dengan adanya ketentuan akad penyimpanan dana dan pembiayaan bagi koperasi syariah ini di harapkan dapat memberikan manfaat terhadap semua pihak yang mempunyai kepentingan dan pada waktunya akan mewujudkan dalam mengelola koperasi syariah yang sehat. Selain itu, kejelasan akad penyimpanan dana dan pembiayaan koperasi syariah dapat membuat kegiatan koperasi menjadi lebih efisien dan menambah kepastian hukum kepada para pihak pelaku, diantaranya untuk para pengelola koperasi dan anggota atau pengguna dana.

Oleh sebab itu peran penting DPS dalam melindungi penegakkan dalam penerapan ketentuan-ketentuan syariah di KSPPS Berkah Abadi Gemilang, maka DPS diberikan wewenang untuk menegur apabila terjadi kesalahan dalam menjalankan kegiatan bahkan memberhentikan operasional apabila telah terbukti mendapatkan adanya kesalahan terhadap ketentuan-ketentuan syariah atas operasional yang dilakukan KSPPS Berkah Abadi Gemilang. Sehingga setatus sebagai keuangan syariah tidak hanya untuk dasar kepentingan bisnis saja, tapi memang benar-benar untuk mewujudkan ketentuan perekonomian islam.

Mengingat begitu besarnya peran dalam menjalankan tugas sebagai Dewan Pengawas Syariah, untuk itu hendaknya tidak semua orang bisa menjalankan peran DPS. Ada syarat khusus yang harus di penuhi supaya seseorang dapat di percaya menjadi DPS. Adapun syarat-syarat untuk menjadi anggota DPS ialah: Mempunyai perilaku yang baik, Harus mempunyai kompetensi pengetahuan dalam bidang syariah mu'amalat serta ilmu pengetahuan dalam bidaang ekonomi syariah modern. Memiliki keinginan yang tinggi untuk memajukan atau mengembangkan perekonomian berdasarkan sisitem syariah. Memiliki kelayakan menjadi DPS yang di buktikan dengan sertifikat dari DSN melalui tes atau uji kompetensi di bidangnya.

Namun dari hasil penelitian yang di lakukan penulis ternyata syarat yang terahir tersebut belum bisa di berlakukan untuk semua lembaga keuangan miko syariah. Salah satunya yaitu ada pada KSPPS Berkah Abadi Gemilang. Bapak Hery Prasetya mengatakan dalam wawancara bahwa.

"Anggota DPS belum ada yang mempunyai sertifikat dari DSN-MUI atau sertifikat standar yang lainnya, karena sulit mencari seorang ulama yang sudah mempunyai sertifikat di daerah sini, bahkan sepertinya malah tidak ada".

Menurut penulis mengenai masalah sertifikat kelayakan, bukan berarti bila DPS belum mempunyai sertifikat kelayakan dari DSN, maka tidak 
mempunyai keahlian untuk menjadi DPS. Karena bisa jadi DPS tidak mencari sertifikat kelayakan sebab sudah mempunyai keahlian/kemampuan, dengan begitu merasa tidak perlu lagi untuk mempunyai sertifikasi kelayakan, juga tidak ingin merasa direpotkan untuk harus mengikuti tes atau ujian yang memerlukan tenaga, pikiran, waktu dan biaya. Namun menurut penulis dengan adanya sertifikat juga penting, sebab dengan sertifikat tersebut bisa menjadikan bukti bahwa calon DPS sudah mempunyai kelayakan untuk menjadi DPS. Dengan demikian dapat lebih mendapatkan keyakinan dan kepercayaan pada kemampuan DPS, karena sudah diuji kemampuannya oleh DSN. selain itu juga bisa menambah rasa percaya maasyarakat terhadap DPS yang sudah mempunyai sertifikat dari DSN-MUI.

Berdasarkan hasil penelitian, di lihat dari kedudukan DPS di KSPPS Berkah Abadi Gemilang adalah suatu lembaga independen yang bertugas melakukan pengawasan syariah terhadap operasional KSPPS. Menurut penulis kesuksesan kegiatan tugas pengawasan dan wewenang pengawasan syariah itu bergantung pada independensinya dalam melakukan suatu penilaian atau keputusan yang diterapkan di KSPPS. Oleh karena itu seharusnya independensinya di harapkan dapat di jamin karena DPS KSPPS Berkah Abadi Gemilang: Bukan pengelola ataupun bagian dari manajemen, sehingga tidak selalu harus mengikuti aturan dari administrasi. Memiliki cara kerja dan tugas-tugas tersendiri sama seperti badan pengawas pada umumnya. Pemilihan dan penentuan gaji dilakukan oleh Rapat Anggota.

\subsubsection{Tugas DPS Berkah Abadi Gemilang}

Hasil penelitian dan pembahasan tentang kedudukan DPS KSPPS Berkah Abadi Gemilang, menunjukkan bahwa DPS KSPPS Berkah Abadi Gemilang memiliki peran yang sangat penting dalam melakukan pengawasan supaya tidak terjadi pelanggaran pada ketentuan-ketentuan syariah. Bahkan penempatan peran penting ini belum sepenuhnya didasari dengan adanya aturan yuridis, atau hukum yang telah di sahkan/diwajibkan oleh pemerintah, akan tetapi penempatan peran penting DPS KSPPS Berkah Abadi Gemilang di dasari dengan kesadaran diri akan rasa semangat dalam melakukan perekonomian syariah yang di wujudkan pada aktifitas KSPPS Berkah Abadi Gemilang sesuai dengan prinsip-prinsip syariah.

Jika di lihat dari kedudukan dan tugasnya, seharusnya DPS KSPPS Berkah Abadi Gemilang dapat menjalankan lima peran:

1) menjadi supervisor, yaitu DPS melakukan pengawasan langsung terhadap kepatuhan syariah, serta memberikan pengawaan pada penerapan fatwa DSN-MUI dalam kegiatan operasional KSPPS.

2) mnjadi advisor, yaitu DPS memberikan saran, nasihat, usulan-usulan sekaligus menjadi konsultan supaya pada pengembangan produk dan jasa yang terbaru untuk persaingan global sesuai dengan ketentuan-ketentuan syariah.

3) menjadi marketer, yaitu DPS sebagai hubungan strategis dalam meningkatkan kuantitas dan kualitas KSPPS lewat komunikasi umum dengan 
memberikan dorongan, memberikan penjelasan dan pembelajaran terhadap masyarakat mengenai pentingnya melakukan muamalah dengan pada ketentuan-ketentuan syariah.

4) Menjadi supporter, yaitu DPS memberikan support atau mendukung, dorongan, pemikiran dan lain-lain supaya pengelola KSPPS agar operasionalnya selalu ada pada jalur prinsip-prinsip syariah sesuai yang di perintahkan didalam Al Qur'an dan As Sunnah.

5) menjadi player, yaitu DPS sebagai pelaku atau pemain dalam perekonomian syariah yang mempunyai tujuan untuk menjaga dan melakukan pengawasan supaya selalu dalam ketentuan-ketentuan syariah.

Melihat dari lima peran diatas bisa membuktikan bahwa DPS mempunyai peran yang paling penting, yaitu dari lima peran itu memiliki tujuan untuk selalu menjaga penerapan dan penegakkan ketentuan-ketentuan syariah khususnya pada kegiatan muamalah. Dewan Pengaws Syariah juga mempunyai kewajiban dalam menjalankan tugasnya. Adapun kewajiban Dewan Pengawas Syariah adalah sebagai berikut: Berpedoman pada fatwa-fatwa DSN-MUI. Mengawasi kegiatan operasional KSPPS supaya tidak melanggar pada prinsip dan ketentuan-ketentuan syariah yang sudah di fatwakan DSN. Memberikan laporan operasional dan perkembangan KSPPS yang di awasinya dengan rutin kepada DSN, minimal satu kali dalam setahun.

Namun dari hasil penelitian yang di lakukan penulis ternyata kewajiban yang point tiga belum di laksanakan oleh Dewan Pengawas Syariah KSPPS Berkah Abadi Gemilang. Dewan Pengawas Syariah tidak pernah melaporkan kegiatan operasional dan perkembangan KSPPS Berkah Abadi Gemilang kepada DSN. hal ini dilakukan karena DPS menganggap bahwa KSPPS Berkah Abadi Gemilang dalam menjalankan operasional sudah sesuai dengan prinsip syariah.

Menurut penulis hal tersebut di atas menjadikan peluang penyimpangan dalam praktik KSPPS terhadap fatwa DSN sangat terbuka. Krena diantaranya tugas dan tanggung jawab DPS KSPPS adalah agar terus memberi pengawasan dan menjaga penerapan fatwa DSN-MUI, tapi DPS KSPPS Berkah Abadi Gemilang belum pernah melaporkan hasil pengawasannya kepada DSN, sehingga DSN tidak mengetahui kegiatan operasional dan penerapan produk yang ada di KSPPS. Kondisi tersebut bisa mengakibatkan dampak negatif pada lemahnya pengawaan syariah di KSPPS. Untuk pelaku yang tidak mempunyai tanggung jawab bisa jadi keadaan seperti ini dapat mempermudah mereka dalam melakukan penyimpangan-penyimpangan terhadap prinsip-prinsip syariah. terlebih lagi bagi KSPPS yang tidak mempunyai DPS, maka akan terjadi peluang penyimpangan yang terbuka lebar baginya.

\subsection{Pelaksanaan Tugas Dewan Pengawas Syariah di KSPPS Berkah Abadi Gemilang Jepara}

Berdasarkan dari hasil penelitian yang penulis lakukan bahwa Dewan Pengawas Syariah dalam menjalankan tugasnya sebagai pengawasan prinsipprinsip syariah kurang optimal. Walaupun pengawasan telah di laksanakan secara 
formal maupun informal. DPS juga sudah memberikan nasihat maupun saransaran kepada pengurus mengenai prinsip syariah, melakukan pengawasan pada jalannya operasioanal KSPPS dan mengevaluasi terhadap produk di KSPPS. Namun DPS belum pernah melaporkan hasil pengawasan atau kinerjanya kepada DSN, DPS juga jarang dalam melakukan kunjungan ke kantor untuk memberikan pengawasan.

Dewan Pengawas Syariah di KSPPS Berkah Abadi Gemilang dalam melakukan pengawasan kepatuhan syariah tidak hanya di lakukan di KSPPS saja, namun juga dalam menjalankan tugasnya menjadi pengawas syariah, ialah memastikan pada anggotanya supaya selalu menganut aturan dalam islam. Hal ini dapat di lihat pada pengawasan secara formal, yaitu bila pengawas memperoleh suatu laporan atau informasi dari pihak lain mengenai suatu hal yang negative yang dalam menjalankan operasional di KSPPS tidak sesuai dengan ketentuan syariah, maka DPS secepatnya untuk mengkroscekkan kepada pengurus atau pengelola mengeni kebenaran laporan. Walaupun DPS mempunyai peranan yang penting serta kedudukan dan kewenangan yang tinggi, namun DPS KSPPS Berkah Abadi Gemilang menggunakan kaidaah tabayyun (mencari penjelasan). DPS tidak seenaknya sendiri dalam memberikan suatu kewenangan dan menjalankan tugastugas sebagi pengawas serta melakukannya dengan hati-hati saat memberikan suatu penilaian.

Untuk mempermudah dalam penerapan kepatuhan syariah, menurut penulis agar operasional yang dijalankan di KSPPS Berkah Abadi Gemilang selalu berada di jalur pada prinsip syariah, maka harus di laksanakan dengan pengawasan secara menyeluruh, yaitu:

1) Riqabah musbaqah adalah pengawasan prefentif yang di lakukan dalam tahapan menyusun suatu produk dan penyusunan suatu rencana,

2) Riqabah lahiqah (pengawasan kegiatan) yang dilaksanakan untuk memastikan praktik dalam bertransaksi diantaranya adalah pelaksanaan akad pembiayaan supaya tidak melanggar dari ketentuan syariah,

3) Riqabah a'mal adalah pengawasan terhadap aktifitas manajemen dan aspek keuangan,

4) Riqabah dzatiyah (pengawasan terhadap moral) pada kesadaran diri pribadi seorang pengelola atau pelaku bisnis tersebut.

Dari beberapa cara pengawasan yang telah disebutkan di atas, yang paling mendasar menurut penulis terdapat pada riqabah dzatiyah, karena sumber suatu pelanggaran muncul adalah dari dalam diri pribadi. Untuk itu pengawasan yang paling efektif ialah di lakukan melalui diri pribadi seorang pelaku bisnis, karena DPS tidak selalu ada setiap waktu untuk melakukan pengawasan. Tapi dengan adanya rasa sadar diri dari dalam hati nurani yang sudah terlatih bahwa meyakini pecaya dengan adanya Allah yang selalu aktif dalam melakukan pengawasan terhadap tingkah laku dan perbuatan manusia, dengan memiliki suatu keyakinan tersebut, maka akan timbul keyakinan yang kuat terhadap firman Allah dalam al Qur'an surat an Nisaa' ayat 1, “....Sesungguhnya Allah selalu menjaga mengawasi kalian." 
Rasa percaya terhadap adanya pengawasan Allah tersebut akan menjadikan pengawasan dalam hati nurani yang bisa menghalangi terhadap penyimpangan kegiatan ekonomi jika di banding dengan pengawasan dari luar. Riqabah dzatiyah ini akan mendorong para pelaku di KSPPS memiliki basis moral yang positif, sehingga menumbuhkan motivasi pengawasan dari dalam, walu tidak di awasi oleh orang lain atau suatu badan yang berwenang (DPS), namun individu yang memiliki riqobah dzatiyah tidak akan berani melakukan penyimpangan terhadap prinsip-prinsip syariah sekecil apapun, karena keyakinan yang kuat bahwa Allah tidak sedetik pun lepas dalam melakukan pengawasan.

Oleh sebab itu semua orang di KSPPS sebagai pelaku bisnis syariah harus di dorong supaya memiliki aqidah yang kuat. Untuk dapat mewujudkan hal demikian, maka manajemen dan semua karyawan di KSPPS harus mampu mendukung dalam mewujudkan terciptanya rasa percaya akan kekuasaan Allah dan memiliki sifat yang jujur pada masing-masing individu. Setiap pelaku bisnis harus mempunyai hati yang bersih dan memiliki keyakinan terhada pengawasan dari Allah. Diperlukan sifat jujur agar dapat melakukan perbuatan sesuai dengan kehendak yang ada dalam hati nuraninya, sebab dari dalam hati nurani yang dapat memberi dorongan untuk melakukan kebenaran. Sedangkan kesadaraan bahwa Allah selalu melakukan pengawaan akan menjadi penghalang yang paling kuat bagi pelaku bisnis ketika mempunyai kesempatan untuk berbuat kesalahan.

\subsection{Praktik Ba'i Bi'saman Ajil Pada Anggota KSPPS Berkah Abadi Gemilang}

Ba'i Bi'saman Ajil adalah akad jual beli suatu barang yang dalam pembayarannya dilakukan dengan cara di cicil, kebalikannya dari jual beli tunai. Dalam hal ini di dasarkan pada kegiatan pembelian dan penjualan. Contoh dalam transaksi ini misal membeli barang dari koperasi, koperasi menjual barang kepada anggota yang telah memesan barang tersebut dengan harga yang sudah di sepakati di awal setelah koperasi dan anggota menentukan jangka waktu dan cara melakukan cicilan. Dalam penentuan harga jual barang dari koperasi kepada nasabah adalah harga awal perolehan di tambah dengan keuntungan (margin). Namun KSPPS Berkah Abadi Gemilang dalam penerapan praktik Ba'i Bi'saman Ajil kepada anggotanya belum sesuai dengan konteks aslinya Ba'i Bi'saman Ajil itu sendiri. KSPPS Berkah Abadi Gemilang menjadikan akad Ba'i Bi'saman Ajil sebagai pembiayaan bukan sebagai akad jual beli.

Bedasarkan hasil penelitian, bahwa KSPPS Berkah Abadi Gemilang memberikan pinjaman berupa uang kepada anggotanya yang di gunakan untuk modal usaha. Dari hasil pinjaman tersebut kemudian anggota membeli barang sendiri sesuai dengan yang di inginkannya. Sedangkan margin yang di terapkan dalam pembiayaan Ba'i Bi'saman Ajil berdasarkan dari presentase jumlah uang yang di pinjamkan pada anggotnya.

Dari penjelasan di atas penulis dapat menyimpulkan bahwa pemberian pembiayaan Ba'i Bi'saman Ajil kepada pelaku usaha adalah kurang tepat, karena akad Ba'i Bi'saman Ajil digunakan berdasarkan pada akad jual beli barang. Seharusnya KSPPS Berkah Abadi Gemilang dalam memberikan pembiayaan untuk kegiatan usaha menggunakan pembiayaan mudharabah dan musyarakah. Dalam 
penentuan margin juga tidak sesuai dengan prinsip syariah, karena di tentukan berdasarkan dari besarnya presentasi uang yang di pinjamkan. Hal demikian itu bisa di kategorikan termasuk dalam praktik riba.

Dari diskusi singkat dengan salah satu marketing KSPPS Berkah Abadi Gemilang bahwa KSPPS kesulitan apabila menggunakan akad Mudharabah, banyak dari anggota belum memahami mengenai keseluruhan pembiayaan termasuk pada pembiayaan Ba'i Bi'saman Ajil, kebanyakan mereka hanya menganggap bahwa sistem pembiayaan di KSPPS lebih mudah di bandingkan dengan sistem pinjam di bank konvensional. KSPPS tidak berani dalam menerapkan akad mudharabah karena dirasa kesulitan dan takut menyimpang dari prinsip syariah. KSPPS juga beranggapan bahwa kebanyakan orang tidak jujur setelah di pinjami modal tapi tidak terus terang dengan keuntungan yang di dapatkan dari hasil usahanya tersebut. Oleh karena itu KSPPS Berkah abadi Gemilang menjadikan akad Ba'i Bi'saman Ajil sebagai pembiayaan untuk mengantisipasi hal yang tidak di inginkan.

\subsection{Hambatan Dewan Pengawas Syariah dan Solusi yang Sudah di Upayakan di KSPPS Berkah Abadi Gemilang Jepara}

Dari data hasil penelitian oleh penulis, bahwa hambatan yang di alami oleh Dewan Pengawas Syariah adalah kurang maksimalnya kunjungan Dewan Pengawas Syariah ke kantor untuk melakukan pengawasan dan keterbatasan ilmu pengetahuan Dewan Pengawas Syariah mengenai fiqh muamalah. Solusi yang sudah diupayakan KSPPS Berkah Abadi Gemilang dalam mengatasi hambatan tersebut ialah pihak koperasi mengambil tindakan dengan menggunakan fatwa MUI dan Peraturan Menteri Koperasi dan UKM untuk di jadikan pedoman dalam membuat dan pelaksanaan suatu transaksi.

Menurut penulis bila dilihat dari syarat-syarat yang ada, pengawasan syariah pada KSPPS Berkah Abadi Gemilang mengalami hambatan tersebut wajar terjadi, di karenakan Dewan Pengawas Syariah di KSPPS Berkah Abadi Gemilang belum mempunyai sertifikat kelayakan dari DSN. Meskipun demikian, dapat dimaklumi karena keterbatasan ulama yang paham terhadap ilmu fiqh muamalah modern dan yang mempunyai sertifikat kelayakan dari DSN. Sehingga lumrah bila masih terdengar adanya banyak pelanggaran pada lembaga keuangan yang tidak sesuai dengan ketentuan syariah di karnakan belum diawasi oleh Dewan Pengawas Syariah yang berkompeten atau telah memenuhi syarat, yaitu selain dari terbatasnnya ilmu yang di miliki juga dikarenakan ketidak optimalan pengawasan serta kurang kesadaran dari dalam diri pribadi masing-masing untuk mewujudkan aspek kepatuhan syariah di lembaga.

Oleh sebab itu sebagaimana yang sudah dibahas sebelumnya dalam kedudukan Dewan Pengawas Syariah KSPPS Berkah Abadi Gemilang, Syarat dalam penetapan DPS semestinya yang sudah benar-benar pantas/ layak, bukan hanya mempunyai semangat keislaman yang tinggi atau pandai dalam berceramah dan rajin dalam beribadahan, akan tetapi juga mempunyai ilmu keahlian dalam bermuamalah dan ilmu ekonomi modern yang memadahi. Syarat sertifikat kelayakan dari DSN juga penting untuk dijadikan sebagai pertimbangan pada lembaga-lembaga keuangan syariah khususnya pada hal ini adalah KSPPS Berkah 
Abadi Gemilang dalam penentuan DPS, sebab dengan adanya sertifikat setidaknya telah memberikan suatu pembuktian bahwa calon DPS sudah lulus uji kelayakan dari DSN. sehingga saat melakukan pengawasan tidak akan mengalami kesulitan karena keterbatasan ilmu yang dimiliki, serta timbulnya rasa kepercayaan masyarakat pada kemampuan Dewan Pengawas Syariah yang telah mempunyai sertifikat dari DSN dan tidak ada keraguan dalam bermuamalah.

\section{PENUTUP}

Peran Dewan Pengawas Syariah KSPPS Berkah Abadi Gemilang Jepara belum optimal. Walaupun dalam menjalankan pengawasan syariah sudah dilakukan secara formal maupun informal. Namun DPS tidak melaporkan kegiatan operasional dan perkembangan KSPPS Berkah Abadi Gemilang kepada DSN, sehingga DSN tidak mengetahui operasional yang ada di KSPPS. Hal ini menjadikan peluang penyimpangan praktik KSPPS terhadap fatwa DSN sangat terbuka. Karena diantara tugas-tugas dan tanggung jawab DPS KSPPS yaitu agar selalu memberi pengawasan dan menjaga dalam penetapan fatwa-fatwa DSN-MUI. DPS juga jarang melakukan kunjungan ke kantor KSPPS untuk melakukan pengawasan. Sehingga masih terdapat kesalahan dalam penerapan praktik Akad Ba'i Bi'saman Ajil kepada anggotanya belum sesuai dengan konteks aslinya dari akad Ba'i Bi'saman Ajil itu sendiri. KSPPS Berkah Abadi Gemilang menjadikan akad Ba'i Bi'saman Ajil sebagai pembiayaan bukan sebagai akad jual beli. Dalam penetapan margin yang di terapkan dalam pembiayaan akad Ba'i Bi'saman Ajil berdasarkan presentase dari uang yang di pinjamkan pada anggotnya, sehingga menimbulkan praktik riba.

Hambatan yang di alami oleh Dewan Pengawas Syariah adalah kurang maksimalnya kunjungan Dewan Pengawas Syariah ke kantor untuk melakukan pengawasan dan keterbatasan ilmu pengetahuan Dewan Pengawas Syariah mengenai fiqh muamalah. Solusi yang sudah diupayakan KSPPS Berkah Abadi Gemilang dalam mengatasi hambatan tersebut ialah pihak koperasi mengambil keputusan sendiri dengan menggunakan fatwa MUI dan Peraturan Menteri Koperasi dan UKM untuk di jadikan tuntunan dalam membuat dan melaksanaan suatu transaksi. 


\section{DAFTAR PUSTAKA}

Abdullah, Ma'ruf. (2016). Hukum Keuangan Syariah. Yogyakarta: Aswaja Pressindo.

Afrizal. Metode Penelitian Kualitatif. Jakata: Raja Grafindo Persada, 2015.

Alfarizy, Shallman. "Pengawasan Baitul Mal Wat-tamwil (BMT) Berbadan Hukum”, 17 November, 2019. https://shallmanalfarizy.com/2017/12/pengawasan -baitulmal-wat-tamwil-bmt-berbadan-hukum/.

Aliyah, Nur, wawancara oleh penulis, wawancara 2, transkrip, 26 Februari, 2020.

Alquran, At-Taubah ayat 105, (2006). Alquran dan Terjemah Indonesia. Kudus: Menara Kudus.

Anggito Albi, dan Johan Setiawan. (2018). Metodologi Penelitian Kualitatif. Sukabumi: CV Jejak.

Anshori, Abdul Ghofur. (2018). Perbankan Syariah di Indonesiaa. Yogyakarta: Gadjah Mada University Press.

Antonio, Muhammad syafi'i. (2001). Bank Syariah: Dari Teori Ke Praktik. Depok: Gema Insani.

Anwar, Aan Zainul dan Mohammad Yunies Edward. (2016). "Analisis Syariah Compliance Pembiayaan Murabahah Pada Gabungan Koperasi BMT Mitra SeKabupaten Jepara", The 3nd University Research Colloquium.

Ardiansyah, Gumelar. "Pengerian Koperasi Syariah Beserta Prinsip dan Landasannya," 23 Desember, 2019 https://guruakutansi.co.id/koperasi-syariah/.

Ascarya. (2013). Akad dan Produk Bank Syariah. Jakarta: Raja Grafindo Persada.

Bugin, Burhan. (2013). Penelitian Kualitatif : Komunikasi, Ekonomi, Kebijakan Publik dan Ilmu Sosial Lainnya Cet VII. Jakarta: Prenada Media Group, 2014.

Burhanuddin. koperasi syariah dan peraturannya di Indonesia. Malang: UIN-Maliki Press.

Darmawan dan Fasa, Muhammad Iqbal. (2020). Manajemen Lembaga Keuangan Syariah. Yogyakarta: UNY Press.

Departemen Pendidikan Nasional. (2012). Kamus Besar Bahasa Indonesia Pusat Bahasa. Jakarta: PT Gramedia Pustaka Utama.

Faozan, Akhmad. (2014). "Optimalisasi Peran Dewan Pengawas Syariah Pada Lembaga Keuangan Syariah El-Jizya,” 2, No. 1.

Fitrah, Muh dan Luthfiyah. (2017). Metodologi Penelitian;Penelitian kualitatif, Tindakan Kelas \& Studi Kasus. Sukabumi: CV Jejak.

Fitriyani, Siti, wawancara oleh penulis, wawancara 10, transkrip, 17 Februari, 2020. 
Gunawan, Imam. (2015). Metode Penelitian Kualitatif Teori \& praktik. Jakarta: PT Bumi aksara.

Hamzah, Amir. (2019). Metode Penelitian Kualitatif. Malang: Literasi Nusantara Abadi.

Hidayat, Faid. (2016). “Alternative Sistem Pengawasan Pada Koperasi Simpan Pinjam dan Pembiayaan Syariah (KSPPS) dalam Mewujudkan Syariria Compliance Mahkamah." 2, No.1.

Hilaluddin, Ahmad, wawancara oleh penulis, wawancara 2, transkrip, 07 juni, 2020.

Ismail. (2004). Perbankkan Syariah. Jakarta: Prenadamedia Group, 2011.

Karim, Adiwarman. Bank Islam Analisis Fiqih dan Keuangan. Jakarta: RajaGrafindo Persada.

Khasyi'ah, Siah. (2014). Fiqh Muamalah Perbandingan. Bandung: Pustaka Setia.

Lewis, Mervvyn dan Latifa Algaoud. (2001). Islamic Banking. Jakarta: PT Serambi Ilmu Semesta.

Mardani. (2015). Aspek Hukum Lembaga Keuangan Syariah di Indonesia. Jakarta: Prenadamedia Group.

Mardian, Sepky. (2015). “Tingkat Kepatuhan Syariah di Lembaga Keuangan Syariah”, Jurnal Akutansi dan Keuangan Islam 3, No. 1.

Moleong, Lexy j. (2010). Metodologi Penelitian Kualitatif, Cet. 27, Bandung: PT Remaja Rosdakarya.

Muhamad. (2014). Manajemen dan Bank Syariah. Jakarta: RajaGrfindo Persada.

Nabhani, Ahmad. "Urgensi Pengawasan Syariah di Koperasi", 14 November 2019. http://www.neraca.co.id/article/101205/urgensi-pengawasan-syariah-di-koperasi.

Noor, Juliansyah. (2012). Metodologi Penelitian: Skripsi, Disertasi dan karya Ilmiah Edisi I. Jakarta: Kencana.

Nopriansyah, Waldi. (2019). Hukum Bisnis di Indonesia Dilengkapi dengan Hukum Bisnis dalam Prespektif Syariah. Jakarta: Prenadamedia Group.

Nurhasanah, Neneng. (2013). "Pengawasan Islam dalam Operasional Lembaga Keuangan Syariah Mimbar," 29, No.1.

Nurhisam, Lukman. (2016). "Kepatuhan syari'ah (Sharia Compiance) dalam Industri Keuangan Syari'ah Ar-Raniry", International Journal Of Islamic Studies 3, No. 1.

Peraturan Menteri Kopersi dan Usaha Kecil Menengah RI. (2017). "11/PER/M.KUKM/XII/2017 Tentang Pelaksanaan Kegiatan Usaha Simpan Pinjam dan Pembiayaan Syariah,". 
Peraturan Menteri Koperasi dan Usaha Kecil dan Menengah RI. (2015). "16/Per/M.KUKM/IX/2015, Tentang Pelaksanaan Kegiatan Usaha Simpan Pinjam dan Pembiayaan Syariah Oleh Koperasi ,".

Prabowo, Bagya Agung dan Jasri Bin Jamal. (2017). "Peran Dewan Pengawas Syariah Terhadap Praktik Kepatuhan Syariah dalam Perbankkan Syariah di Indonesia”, Jurnal Hukum Ius QuiaIustum Faculty of Law 24, No. 1.

Prasetya, Hery, wawancara oleh penulis, wawancara 7, transkrip, 17 Februari, 2020.

Prastowo, Andi. (2016). Memahami Metode-Metode Penelitian, cet.III. Jogjakarta: ArRuz Media.

Qoniatin, wawancara oleh penulis, wawancara 4, transkrip, 26 Februari, 2020.

Rahma, Fayruz. (2018). "Rancang Bangun Sistem Informasi Koperasi Simpan Pinjam Pembiiayaan Syariah Berbasis Kelompok", Jurnal Naional Teknologi dan Sistem Informasi 4, No. 01.

Ridwan, Ahmad Hasan. (2013). Manajemen Baitul Mal Wa Tamwil. Bandung: Pustaka Setia.

Sattar. (2017). Buku Ajar Ekonomi Koperasi, Yogyakarta: CV Budi Utama.

Sholihin, Ahmad Ifham. (2013). Buku Pintar Ekonomi Syariah. Jakarta: Gramedia Pustaka Utama.

Sjahdeini, Sultan Remy. (2014). Perbankkan Syariah Produk-Produk dan AspekAspek Hukumnya. Jakarta: Kencana.

Soemitra, Andri. (2009). Bank dan Lembaga Keuangan Syariah,. Jakarta: Prenadamedia Group.

Sofiani, Triana. (2014). "Konstruksi Norma Hukum Koperasi Syariah Dalam Kerangka Sistem Hukum Koperasi Nasional”, Jurnal Hukum Islam 12, No .9.

Sofiyah. (2012). “Analisis Efektifitas Keputusan DSN-MUI No. 3 Tahun 2000 Berkaitan dengan Dewan Pengawas Syariah di Baitul Mal Wa Tamwil (BMT) Studi Kasus di BMT Bima Magelang," Jurnal Muqtasid 3, No.1.

Sudarsono, Heri. (2004). Bank dan Lembaga Keuangan Syariah Deskripsi dan Ilustrasi. Yogyakarta: Ekonisia.

Sugiyono. (2015). Metode Penelitian Pendidikan (pendekatan kualitatif, kuantitatif dan R\&D. Bandung: Alfabeta.

Suryabrata, Sumardi. (2005). Metodologi Penelitian. Jakarta: PT Raja Grafindo Persada.

Susilo, Edi. (2017). Sariah Compliance Akad Rahn Lembaga Keuangan Mikro Syariah (Studi Kasus BMT Mitra Muamalah Jepara) Iqtishadia." Jurnal Ekonomi dan Peerbankkan Syariah 4, No.1. 
Sutanto, Herry dan Khaerul Umam. (2013). Manajemen Pemasaran Bank Syariah. Bandung: CV Pustaka Setia.

Sukarli, Syukri, wawancara oleh penulis, wawancara 8, transkrip, 20 Februari, 2020.

Syafaat, Muhammad, wawancara oleh penulis, wawancara 1, transkrip, 25 Februari, 2020.

Umam, Khaerul. (2013). Manajemen Perbankkan Syariah. Bandung: Pustaka Setia.

Umam, Khotibul dan Setiawan Budi Utomo. (2016). Perbankkan Syariah: Dasar-Dasar dan Dinamika Perkembangannya di Indonesia. Jakarta: RajaGrafindo Persada.

Umam, Khotibul dan Veri Antoni. (2018). Corporate Action Pembentukan Bank Syariah. Yogyakarta: UGM Press.

Usman, Rachmadi. (2009). Produk dan Akad Perbankkan Syariah di Indonesia. Bandung: PT Citra Aditya Bakti.

Wangsawidjaja. (2012). Pembiayaan Bank Syariah. Jakarta: Gramedia Pustaka Utama.

Wijaya, Hengki. (2018). Analisis Data Kualitatif Ilmu Pendidikan Teologi. Makasar: Sekolah Tinggi Theologia Jaffray.

Yusuf, A. Muri. (2014). Metode Penelitian Kuantitatif, Kualitatif dan Penelitian Gabungan Cet I. Jakarta : Fajar Interpratama Mandiri.

Zaidun, wawancara oleh penulis, wawancara 2, transkrip, 26 Februari, 2020.

Zuhriyah, Nurul. (2006). Metode Penelitian Sosial dan Pendidikan. Jakarta: PT Bumi aksara.

“Dinas Koperasi, Usaha Kecil Dan Menengah Kabupaten Gunungkidul," Dewan $\begin{array}{lllll}\text { Pengawas } & \text { Syariah. } & 9 & \text { Januari, }\end{array}$ https://kukm.gunungkidulkab.go.id/berita-92/dewan-pengawassyariah.html.

"Tahun 2018, Pertumbuhan KSPPS Masih Akan Alami Perlambatan." Sharianews. 14 November, 2019. https://sharianews.com/posts/tahun-2018-pertumbuhankspps-masih-akan-alami-perlambatan. 